\title{
SHARIA MUTUAL FUNDS PERFORMANCE IN INDONESIA
}

\author{
Robiyanto ROBIYANTO ${ }^{1}$, Michael Alexander SANTOSO ${ }^{2}$, Rihfenti ERNAYANI ${ }^{3}$ \\ 1,2 Satya Wacana Christian University, Salatiga, Indonesia \\ ${ }^{3}$ University of Balikpapan, Balikpapan, Indonesia

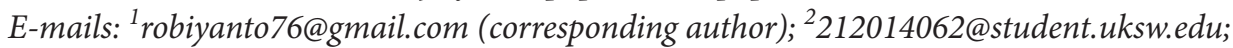 \\ ${ }^{3}$ rihfenti@uniba-bpn.ac.id
}

Received 17 October 2018; accepted 03 December 2018

\begin{abstract}
The study aims to measure each Sharia mutual fund performance and compare with market performance in Indonesia. Sharia mutual fund investment instruments in Indonesia have positive developments over the period from 2012 to 2017 . These positive developments add to the option of investment instruments for public, especially investors who put forward the principles of Sharia. This research was conducted so that the public could have scientific information about Sharia mutual funds that have the best performance. The study found consistent results regarding Sharia mutual funds with the best performance on Sharpe and Jensen measurement methods. The best performing Sharia mutual fund by using those methods was PNM Syariah, while the lowest-performing mutual fund was PNM Amanah Syariah if measured by using Sharpe Index and PNM Ekuitas Syariah if measured by using Jensen Alpha. Different results were found when Sharia mutual fund performance was measured using Treynor Ratio Information Ratio, where the best Sharia mutual fund performance was by Manulife Syariah Sectoral Amanah mutual fund while the lowest performance was by Cipta Syariah Equity mutual fund. This findings are expected to be useful for Sharia-based investors.
\end{abstract}

Keywords: Sharia mutual fund, Jensen Index, Sharpe Index, Treynor Ratio, Information Ratio.

JEL Classification: G11.

\section{Introduction}

The development of the investment world especially in Indonesian capital market has shown a positive development, as seen from the benchmark index based on the OJK (2017a), the Jakarta Composite Index (JCI) shows an upward trend in the last six years. This positive trend proves that investment, especially in capital markets, is increasingly becomes a necessity for society. However, Waridah and Mediawati (2016) said that there are obstacles for investors to be able to invest funds in the capital market, such as the knowledge, information or limited time. Thus, alternative investment instruments that can be used as a solution to these barriers are mutual funds (Pangestuti et al. 2017).

Mutual funds can be regarded as one of diversification strategies in the investment activity and also an alternative instrument of investment for society as an investor, especially the investors with limited time and ability to calculate risk on the investment (Waridah and Mediawati 2016). Indonesia, as one of the largest Muslim-majority countries in the world, is a promising reason for the development of the Islamic finance industry. On July $3^{\text {rd }}, 1997$, Sharia mutual funds were first issued by PT. Danareksa. The presence of Sharia mutual funds further complements the existing diversity of conventional mutual fund investment options (Arifin 2017). Pangestuti et al. (2017), Qomariah et al. (2016) stated that based on its asset portfolio, mutual funds are divided into four categories, namely money market mutual funds, stock mutual funds, fixed income mutual funds, and mixed mutual funds.

Sharia-based mutual funds have different criteria from the conventional mutual funds, as set out in the former regulation called Bapepam-LK or now called as the Financial

Copyright $\odot 2019$ The Authors. Published by VGTU Press.

This is an Open Access article distributed under the terms of the Creative Commons Attribution License (http://creativecommons.org/licenses/by/4.0/), which permits unrestricted use, distribution, and reproduction in any medium, provided the original author and source are credited.. 
Services Authority (FSA) (or OJK, Otoritas Jasa Keuangan) Number.IX.A.13 stating that the selection of investment instruments and investment mechanisms should not be against the Sharia principle which does not impose measures such as usury, gambling, ambiguity, bribery, and exploitation (Ismal 2009, Wahyudi et al. 2018). Thus, funds are only invested in companies that are halal or unrelated to gambling, cigarette, alcohol, pornography and other things that are not allowed or prohibited in Islamic Sharia Law (Abdul-Rahman and Yazid 2015, Hilman 2017, Sukmana and Febriyati 2016).

Based on OJK (2017b), Sharia mutual fund investment instruments had a positive development over the period from 2012 to 2017 regarding both product quantity and Net Asset Value (NAV). According to Waridah and Mediawati (2016), Net Asset Value is the market value of the fair and the wealth of a mutual fund substracted by the obligation and then divided by the total investment units owned by all investors in the mutual fund so that it can be a benchmark on the results of a mutual fund. The increasing NAV is an indication of the increase in investment value per unit of participation. These positive developments add to the option of investment instruments for the community, especially investors who prioritize the principles of Sharia. However, there is still a concern faced by the investors that the funds invested in Sharia mutual funds cannot provide a better return or yield than when the funds are invested into the conventional mutual fund instruments, due to the limitation of allocated investment funds that are less than optimal. This statement is quite reasonable considering the products of Sharia-based mutual funds in Indonesia show that the number is still limited (Hilman 2017). Furthermore, Hilman (2017) said that it is important to understand the performance of mutual funds before selecting the existing Sharia mutual fund alternative.

Based on the background described above, the object of this study was devoted to the Sharia mutual funds with the category of Sharia mutual funds namely mixed, stocks, fixed income, and money market which are active during the period of 2011-2016. The reason for choosing the period was to address the gap of several earlier studies, i.e. researches by Hilman (2017), Lestari (2015), Sunarsih and Andriyanto (2015), Waridah and Mediawati (2016). Therefore, this study used the period that could represent the study period used by the four previous researchers. Meanwhile, the performance measurement method applied in this research referred to the researches by Pangestuti et al. (2017), Pratomo and Nugraha (2009), Robiyanto (2017, 2018), Robiyanto et al. (2017) which used Sharpe, Jensen, Treynor, and Information Ratio methods, considering that the previous researches described only measured the performance with the Sharpe, Jensen, and Treynor methods.

\section{Literature review}

Sahri et al. (2015) stated that in measuring the performance of mutual funds, it is not enough the calculation is only based on the total return, but it is necessary to consider the risk factors. It is based on the measurement of the performance of mutual funds that if risk factors are considered, it will provide more in-depth information to investors about the performance or outcome of the mutual funds associated with the risks taken to achieve such performance. Thus, the evaluation of mutual fund performance can be performed by using performance measurement that considers risk and returns, i.e., Risk-Adjusted Return (RAR) such as Sharpe, Jensen, and Treynor methods (Kidd 2011b, Loeis and Prijadi 2015, Pratomo and Nugraha 2009). Further, Kidd (2011a), Nadifa (2016) have argued that the mutual fund performance measurement is also commonly done by using the Information Ratio method.

Researches on the performance analysis of Sharia mutual funds have also been conducted by several previous researchers, such as a research by Waridah and Mediawati (2016) which examined specifically on the Sharia equity mutual fund instruments using Sharpe Ratio performance measurement method during the 2010-2014 period. It was concluded that Cipta Syariah Equity mutual fund was the best performing Sharia mutual fund with Sharpe ratio of -0.349 and PNM Ekuitas Syariah became the lowestperforming Sharia mutual fund during that period with a Sharpe ratio of -1.232 . Overall, during the observation period, the Sharpe ratio value of all Sharia mutual funds in the study resulted in a negative Sharpe ratio, meaning that the return generated by the mutual funds in the sample was not higher than their risk-free return.

Similar research on the Sharia equity mutual funds had also been done by Lestari (2015) using Sharpe Ratio method during the 2011-2013 period where the best Sharia mutual fund performance was by Batavia Dana Saham Syariah with Sharpe's value of 7.357 and the lowest Sharia mutual fund performance was by Mandiri Investa Atraktif Syariah with Sharpe ratio value of 2.056 . While a research conducted by Hilman (2017) on the Sharia equity mutual fund instrument during the 2014-2016 period using Sharpe method showed that the Batavia Dana Saham Syariah was not the best performing Sharia equity fund, but the Cipta Syariah Equity with Sharpe ratio of 13.964 and the lowest performance was by MNC Dana Syariah with Sharpe ratio value of -3.203 .

Sunarsih and Andriyanto (2015) reviewed the performance of Sharia mutual funds using the Sharpe, Treynor and Jensen methods during the period 2010-2012 and found inconsistent results from all three measurement methods in each of the same periods. In Sharpe's method in 2010, it showed the best performance of Sharia mutual funds was by PNM Amanah Syariah with a value of 0.786 and the lowest performance was by Sam Sukuk Syariah Sejahtera with a 
value of 0.195 . While in 2011 , the best Islamic mutual fund performance was by MNC Syariah Fund with a value of 1.199 and the lowest performance was by IPB Syariah with a value of -0.287 . While in the final period of the research, in 2012, it showed that the best performance of Sharia mutual funds was by Haji Syariah with a value of 1.386 and the lowest performance was by PNM Amanah Syariah with a value of -0.540 .

While using the Treynor method, Sunarsih and Andriyanto (2015) in 2010 found that the best performance of Sharia mutual funds was by BNI Dana Syariah Funds with a value of 0.57388 and the lowest performance was by MNC Dana Syariah with a value of -1.130 . While in 2011, the best performance of Sharia mutual funds was by Mandiri Investa Dana Syariah with the value of 1.053 and the lowest performance was by Haji Syariah with a value of -1.802 . Different results were also found in 2012 where the best performance was by MNC Dana Syariah with a value of 0.186 , and the lowest performance was by Haji Syariah with a value of -0.311 .

\subsection{Theory of modern portfolio and mutual fund}

The modern portfolio theory was introduced by Markowitz (1952) who suggested that there are two approaches in investment portfolios, namely the classical and modern portfolio approach. The classical approach emphasizes efficiency. Markowitz used mean-variance analysis to form efficient portfolios, namely portfolios that provide the highest returns for a certain level of risk. Therefore, the Markowitz Efficient portfolio was also called the mean-variance efficient portfolio. Whereas in the modern portfolio theory approach to investment, it started with the assumption that investors have spent a certain amount of money on investment these days. This money will be invested for a certain period of time which is called as the investor's holding period.

Modern portfolio theory has become the main guideline that supports portfolio allocation decisions for various investment instruments such as mutual funds, retirement funds, and other institutions that seek maximum portfolio investment returns and minimize risk. Modern portfolio theory examines the way investors who have risk avoidance characteristics to be able to form optimal portfolios by considering the exchange between market risk and expected returns. The theory calculates the benefits of diversification. The investors can determine the efficient frontier of optimal portfolio. Each portfolio on an efficient frontier offers maximum return expectations at a certain level of risk. Investors can hold an optimal portfolio on efficient frontier by borrowing or lending government bonds which are risk-free securities.

\subsection{Portfolio performance measurement methods}

The modern portfolio theory introduced by Markowitz (1952) was later developed and refined by Markowitz (1959). This modern portfolio theory largely underlies various portfolio measurement methods. For example, Sharpe Index developed by Sharpe (1966) was originally introduced to measure the performance of mutual funds in the United States. Sharpe Index has been widely used by the financial industry because of its simplicity and makes it easy for practitioners and academics to assess portfolio performance (Pangestuti et al. 2017). Sharpe Index is a measurement that uses a unit return calculation subtracted by the risk-free yield rate compared to total risk. This is commonly referred to as reward to variability (Ferruz et al. 2010). In other words, the Sharpe Index focuses on measuring portfolio performance based on an unsystematic risk.

Unlike the Sharpe Index, Treynor (1965) introduced Treynor Ratio which calculates systematic return per unit risk. The Formula of Treynor Ratio measures returns subtracted by the risk-free return on each market risk unit. The method of measuring Treynor Ratio is often referred to as reward to volatility (Beer et al. 2011). Jensen (1967) also created a portfolio performance measurement tool called Jensen Alpha. Jensen Alpha is a special measurement for risk-adjusted returns from portfolio performance which specifically emphasizes a systematic risk. In addition to these measurement methods, Information Ratio was developed from Sharpe Ratio (Kidd 2011b). The difference is that Information Ratio also uses the benchmark return in its calculations.

\section{Research methodology}

The type of research used was descriptive research with quantitative approach. While the population in this study were the Sharia mutual funds registered in the Financial Services Authority (OJK). Based on the latest data from OJK per August 2017, the population of active Sharia mutual funds during the period were 160 Sharia mutual funds. However, not all 160 Sharia mutual funds would be used in this study sample. The sampling technique used was a purposive sampling technique. The criteria applied in this research were that the Sharia mutual fund consisted of stocks, money market, fixed income and mixed mutual funds which were active during the 2011-2016 period and registered in OJK. Based on these criteria, the number of samples used was as many as 23 Sharia mutual funds. The 23 Sharia mutual funds were then re-selected based on the availability of NAV data contained in the Pusat Data Kontan (2017), so that the sample used in this study was only 21 Sharia mutual funds. Table 1 shows a sample of 21 Sharia mutual funds used in this study. 
This research data used a secondary data type obtained from published sources. The required data were the monthly data of Net Asset Value (NAV) of each Sharia mutual fund, Jakarta Islamic Index (JII), and interest rate during the 2011-2016 period. The data on NAB was obtained from pusatdata.kontan.co.id, and the Jakarta Islamic Index data was obtained from Bloomberg Data Feed, and the interest rates data was obtained from Bank Indonesia (2018).

The variables used in this study were Sharia mutual funds return, Jakarta Islamic Index returns used as market return proxy, risk-free rate of return, standard deviation, and beta. All of these variables were important to calculate the Sharpe Index, Treynor Ratio, Jensen Alpha, and Information Ratio. Sharpe Index, Treynor Ratio, Jensen Alpha, and Information Ratio were the most common method and widely used as portfolio performance measurement in the financial world (Kidd 2011a, Robiyanto et al. 2017, Zulkafli et al. 2017). All variables are explained below.

\subsection{Sharia mutual funds return}

Mutual fund returns for a period can be seen from the $\mathrm{NAV} /$ unit data. Below is the formula of mutual fund return:

$$
R i=\frac{N A B_{t}-N A B_{t-1}}{N A B_{t-1}},
$$

whereas: $R i=$ Sharia Mutual Funds Return; $N A B_{t}=$ Sharia Mutual Funds NVA in period $t ; N A B_{t-1}=$ Sharia Mutual Funds NVA in period $t-1$.

\subsection{Jakarta Islamic Index (JII) return}

JII return was used as a benchmark variable for the performance of mutual funds and also the market return. Below is the formula of JII return:

$$
R_{m t}=\frac{J I I_{t}-J I I_{t-1}}{J I I_{t-1}},
$$

whereas: $R_{m t}=J I I$ Return as proxy of market return in period $t ; J I I_{t}=J I I$ in period $t ; J I I_{t-1}=J I I$ in period $t-1$.

\subsection{Risk-free rate of return}

Risk-free rate of return is the average return of risk-free investment (Robiyanto 2017, Triyono and Robiyanto 2017). This study used the interest rate of Bank Indonesia or BI rate.

\subsection{Standard deviation}

Standard deviation was used to measure the level of risk of a mutual fund about the likelihood of return rate variability occurrence obtained by an asset. Below is the formula of the standard deviation of Sharia mutual funds:

$$
\sigma=\sqrt{\sigma^{2}}=\sqrt{\sum(R i-\overline{R i})^{2} / n-1},
$$

\begin{tabular}{|c|c|c|c|}
\hline No & $\begin{array}{l}\text { Sharia Mutual } \\
\text { Funds' Name }\end{array}$ & Investment Manager & Type \\
\hline 1 & PNM Syariah & $\begin{array}{l}\text { PT. PNM Investment } \\
\text { Management }\end{array}$ & Mixed \\
\hline 2 & $\begin{array}{l}\text { Danareksa Syariah } \\
\text { Berimbang }\end{array}$ & $\begin{array}{l}\text { PT. Danareksa } \\
\text { Investment } \\
\text { Management }\end{array}$ & Mixed \\
\hline 3 & $\begin{array}{l}\text { PNM Amanah } \\
\text { Syariah }\end{array}$ & $\begin{array}{l}\text { PT. PNM Investment } \\
\text { Management }\end{array}$ & $\begin{array}{l}\text { Fixed } \\
\text { Income }\end{array}$ \\
\hline 4 & $\begin{array}{l}\text { Mandiri Investa } \\
\text { Syariah Berimbang }\end{array}$ & $\begin{array}{l}\text { PT. Mandiri } \\
\text { Manajemen Investasi }\end{array}$ & Mixed \\
\hline 5 & MNC Dana Syariah & $\begin{array}{l}\text { PT. MNC Asset } \\
\text { Management }\end{array}$ & $\begin{array}{l}\text { Fixed } \\
\text { Income }\end{array}$ \\
\hline 6 & I-Hajj Syariah Fund & $\begin{array}{l}\text { PT. Insight } \\
\text { Investments } \\
\text { Management }\end{array}$ & $\begin{array}{l}\text { Fixed } \\
\text { Income }\end{array}$ \\
\hline 7 & $\begin{array}{l}\text { AAA Amanah } \\
\text { Syariah Fund }\end{array}$ & $\begin{array}{l}\text { PT. AAA Asset } \\
\text { Management }\end{array}$ & Mixed \\
\hline 8 & $\begin{array}{l}\text { TRIM Syariah } \\
\text { Berimbang }\end{array}$ & $\begin{array}{l}\text { PT. Trimegah Asset } \\
\text { Management }\end{array}$ & Mixed \\
\hline 9 & $\begin{array}{l}\text { TRIM Syariah } \\
\text { Saham }\end{array}$ & $\begin{array}{l}\text { PT. Trimegah Asset } \\
\text { Management }\end{array}$ & Equity \\
\hline 10 & $\begin{array}{l}\text { Mega Dana Obligasi } \\
\text { Syariah }\end{array}$ & $\begin{array}{l}\text { PT. Mega Capital } \\
\text { Investama }\end{array}$ & $\begin{array}{l}\text { Fixed } \\
\text { Income }\end{array}$ \\
\hline 11 & $\begin{array}{l}\text { Batavia Dana Saham } \\
\text { Syariah }\end{array}$ & $\begin{array}{l}\text { PT. Batavia } \\
\text { Prosperindo Aset } \\
\text { Manajemen }\end{array}$ & Equity \\
\hline 12 & $\begin{array}{l}\text { PNM Ekuitas } \\
\text { Syariah }\end{array}$ & $\begin{array}{l}\text { PT. PNM Investment } \\
\text { Management }\end{array}$ & Equity \\
\hline 13 & $\begin{array}{l}\text { CIMB-Principal } \\
\text { Islamic Equity } \\
\text { Growth Syariah }\end{array}$ & $\begin{array}{l}\text { PT. CIMB-Principal } \\
\text { Asset Management }\end{array}$ & Equity \\
\hline 14 & $\begin{array}{l}\text { Mandiri Investa } \\
\text { Atraktif Syariah }\end{array}$ & $\begin{array}{l}\text { PT. Mandiri } \\
\text { Manajemen Investasi }\end{array}$ & Equity \\
\hline 15 & $\begin{array}{l}\text { Cipta Syariah } \\
\text { Balance }\end{array}$ & $\begin{array}{l}\text { PT. Ciptadana Asset } \\
\text { Management }\end{array}$ & Mixed \\
\hline 16 & Cipta Syariah Equity & $\begin{array}{l}\text { PT. Ciptadana Asset } \\
\text { Management }\end{array}$ & Equity \\
\hline 17 & $\begin{array}{l}\text { Mandiri Investa } \\
\text { Dana Syariah }\end{array}$ & $\begin{array}{l}\text { PT. Mandiri } \\
\text { Manajemen Investasi }\end{array}$ & $\begin{array}{l}\text { Fixed } \\
\text { Income }\end{array}$ \\
\hline 18 & $\begin{array}{l}\text { Manulife Syariah } \\
\text { Sektoral Amanah }\end{array}$ & $\begin{array}{l}\text { PT. Manulife Aset } \\
\text { Manajemen Indonesia }\end{array}$ & Equity \\
\hline 19 & $\begin{array}{l}\text { Schroder Syariah } \\
\text { Balanced Fund }\end{array}$ & $\begin{array}{l}\text { PT. Schroder } \\
\text { Investment } \\
\text { Management } \\
\text { Indonesia }\end{array}$ & Mixed \\
\hline 20 & $\begin{array}{l}\text { SAM Sukuk Syariah } \\
\text { Sejahtera }\end{array}$ & $\begin{array}{l}\text { PT. Samuel Aset } \\
\text { Manajemen }\end{array}$ & $\begin{array}{l}\text { Fixed } \\
\text { Income }\end{array}$ \\
\hline 21 & $\begin{array}{l}\text { SAM Syariah } \\
\text { Berimbang }\end{array}$ & $\begin{array}{l}\text { PT. Samuel Aset } \\
\text { Manajemen }\end{array}$ & Mixed \\
\hline
\end{tabular}

Table 1. Sharia mutual funds' sample list (source: Pusat Data Kontan (2017) and Financial Services Authority (2017b)) 
whereas: $\sigma=$ Standard deviation; $\sigma^{2}=$ Variance; $R i=$ Sharia mutual funds return; $\bar{R} i=$ Sharia mutual funds average return; $n=$ number of observations.

\subsection{Beta $(\beta)$}

Beta is used to measure the systematic risk of a portfolio against market risk (Robiyanto 2017). Below is the formula of Sharia mutual funds beta:

$$
\beta p=\frac{\operatorname{Cov}(R i \cdot R m)}{\sigma^{2} m},
$$

whereas: $\beta p=$ Sharia mutual funds return; $\operatorname{Cov}(R i \cdot R m)=$ Covariance of Sharia mutual funds return, market return; $\sigma^{2} m=$ Market variance.

\subsection{Sharpe Index}

Sharpe Index is a method of measuring performance by comparing the difference between the average rate of portfolio profit and the average risk-free rate with the total risk (standard deviation) portfolio. Below is the formula of Sharpe Index (Robiyanto 2017):

$$
S i=\frac{\left(R i_{t}-R f_{t}\right)}{\sigma i_{t}},
$$

whereas: $S i=$ Sharpe Index; $R i_{t}=$ Sharia mutual fund return in period $t ; R f_{t}=$ Risk free rate return in period $t ; \sigma i_{t}=$ Standard deviation of Sharia mutual fund in period $t$.

\subsection{Treynor Ratio}

The Treynor Ratio, in essence, is not much different from Sharpe's method of comparing the difference between average portfolio returns and average risk-free interest rates. However, the risk used in the Treynor method is not the total risk, but the systematic risk (beta). Below is the formula of Treynor Ratio (Lakaba and Robiyanto 2018, Pangestuti et al. 2017):

$$
T i=\frac{\left(R i_{t}-R f_{t}\right)}{\beta i_{t}},
$$

whereas: $T i=$ Treynor Ratio; $R i_{t}=$ Sharia mutual fund return in period $t ; R f_{t}=$ Risk free rate return in period $t ; B i_{t}=$ Beta of Sharia mutual fund in period $t$.

\subsection{Jensen Alpha}

Jensen's measurement method considers the excess return that a portfolio obtains which is more than the expected results, the measurement of this method also known as alpha. Below is the formula of Jensen Alpha (Robiyanto 2018):

$$
\alpha_{p}=R i_{t}-\left[R f_{t}+\left(R m_{t}-R f_{t}\right) \beta_{p}\right],
$$

whereas: $R i_{t}=$ Sharia mutual fund return in period $t ; R f_{t}=$ Risk free rate return in period $t ; \alpha_{p}=$ Jensen's alpha; $\beta_{p}=$
Beta of Sharia mutual fund in period $t ; R m_{t}=$ market return in period $t$.

\subsection{Information ratio}

The value of information ratios is derived from calculating the return of the mutual fund subtracted by the benchmark return then divided by the standard deviation difference from the return of the fund and the market. If the ratio of mutual fund information is positive or greater than the ratio of market information (always zero), then it can be said that the performance of mutual funds is good (Nadifa 2016). Below is the formula of Information Ratio (Kidd 2011b):

$$
I R=\frac{R_{p}-R_{b}}{\sigma_{p-b}},
$$

where $I R=$ Information Ratio; $R_{p}=$ Sharia mutual fund return; $R_{b}=$ Benchmark Return /JII Return; $\sigma_{p-b}=$ Standard deviation differences between Sharia mutual fund return and benchmark return.

\section{Research results and discussion}

This section presents the results of the study by using the specified methodology to measure and compare the Sharia mutual fund performance. Table 2 presents the results of Sharia mutual fund performance measurement using Sharpe Index, Treynor Ratio, Jensen Alpha, and Information Ratio methods during the 2011-2016 study period.

Based on the results of performance measurement by using Sharpe Index in Table 2, it shows that from 21 samples, there are 11 Sharia mutual funds with positive performance and ten other Sharia mutual funds which have a negative performance. The measurements made using this Sharpe Index indicated that there were 11 Sharia mutual funds worthy of choice for the investment of total samples of 21 Sharia mutual funds. It was because the performance of the Sharia mutual funds was positive by using the Sharpe Index. The mean returns generated from the 11 Sharia mutual funds exceed the return of risk-free investment. The greater the value Sharpe Index, the better the performance of a Sharia mutual fund. It was because it could generate a high return on the total risk (systematic risk and unsystematic risk) that it borne. Therefore, based on the calculations using the Sharpe Index, the Shariah mutual funds that have the best performance is PNM Syariah with Sharpe Index of 0.211. While the lowest performance is by PNM Amanah Syariah with Sharpe Index value of -0.257 .

The performance measurement using Treynor Ratio in Table 2 shows a relatively similar result with the Sharpe Index. Out of 21 samples, only 11 Sharia mutual fund which have a positive performance. It indicated that they were worth to be an investment, while ten other Sharia mutual funds with negative performance indicated that they were not feasible 
Table 2. Sharia mutual funds' Sharpe Index, Treynor Ratio, Jensen Alpha, and Information Ratio (source: Pusat Data Kontan (2017) and Financial Services Authority (2017b), processed)

\begin{tabular}{|c|c|c|c|c|c|}
\hline No. & $\begin{array}{c}\text { Mutual Fund } \\
\text { Name }\end{array}$ & $\begin{array}{l}\text { Sharpe } \\
\text { Index }\end{array}$ & $\begin{array}{c}\text { Treynor } \\
\text { Ratio }\end{array}$ & $\begin{array}{l}\text { Jensen } \\
\text { Alpha }\end{array}$ & $\begin{array}{l}\text { Infor- } \\
\text { mation } \\
\text { Ratio }\end{array}$ \\
\hline 1. & PNM Syariah & 0.211 & 0.019 & 0.006 & 0.558 \\
\hline 2. & $\begin{array}{l}\text { Danareksa Sya- } \\
\text { riah Berimbang }\end{array}$ & -0.025 & -0.002 & -0.001 & 0.146 \\
\hline 3. & $\begin{array}{l}\text { PNM Amanah } \\
\text { Syariah }\end{array}$ & -0.257 & -0.655 & -0.002 & 0.080 \\
\hline 4. & $\begin{array}{l}\text { Mandiri } \\
\text { Investa Syariah } \\
\text { Berimbang }\end{array}$ & -0.060 & -0.005 & -0.002 & 0.146 \\
\hline 5. & $\begin{array}{l}\text { MNC Dana } \\
\text { Syariah }\end{array}$ & 0.074 & 0.016 & 0.000 & 0.005 \\
\hline 6. & $\begin{array}{l}\text { I-Hajj Syariah } \\
\text { Fund }\end{array}$ & -0.004 & -0.003 & 0.000 & 0.016 \\
\hline 7. & $\begin{array}{l}\text { AAA Amanah } \\
\text { Syariah Fund }\end{array}$ & -0.022 & -0.002 & -0.001 & 0.092 \\
\hline 8. & $\begin{array}{l}\text { TRIM Syariah } \\
\text { Berimbang }\end{array}$ & 0.068 & 0.006 & 0.002 & -0.264 \\
\hline 9. & $\begin{array}{l}\text { TRIM Syariah } \\
\text { Saham }\end{array}$ & 0.060 & 0.005 & 0.002 & 0.561 \\
\hline 10. & $\begin{array}{l}\text { Mega Dana } \\
\text { Obligasi Syariah }\end{array}$ & -0.120 & -0.040 & -0.002 & 0.078 \\
\hline 11. & $\begin{array}{l}\text { Batavia Dana } \\
\text { Saham Syariah }\end{array}$ & 0.004 & 0.000 & 0.000 & -0.118 \\
\hline 12. & $\begin{array}{l}\text { PNM Ekuitas } \\
\text { Syariah }\end{array}$ & -0.117 & -0.010 & -0.006 & -1.139 \\
\hline 13. & $\begin{array}{l}\text { CIMB-Principal } \\
\text { Islamic Equity } \\
\text { Growth Syariah }\end{array}$ & -0.054 & -0.004 & -0.003 & -1.646 \\
\hline 14. & $\begin{array}{l}\text { Mandiri Investa } \\
\text { Atraktif Syariah }\end{array}$ & -0.063 & -0.005 & -0.003 & -2.342 \\
\hline 15. & $\begin{array}{l}\text { Cipta Syariah } \\
\text { Balance }\end{array}$ & 0.002 & 0.000 & 0.000 & 0.054 \\
\hline 16. & $\begin{array}{l}\text { Cipta Syariah } \\
\text { Equity }\end{array}$ & 0.070 & 0.006 & 0.003 & -3.362 \\
\hline 17. & $\begin{array}{l}\text { Mandiri Investa } \\
\text { Dana Syariah }\end{array}$ & 0.108 & 0.028 & 0.005 & 0.559 \\
\hline 18. & $\begin{array}{l}\text { Manulife } \\
\text { Syariah Sektoral } \\
\text { Amanah }\end{array}$ & 0.025 & 0.002 & 0.001 & 0.796 \\
\hline 19. & $\begin{array}{l}\text { Schroder } \\
\text { Syariah } \\
\text { Balanced Fund }\end{array}$ & 0.083 & 0.007 & 0.002 & -0.100 \\
\hline 20. & $\begin{array}{l}\text { SAM Sukuk } \\
\text { Syariah } \\
\text { Sejahtera }\end{array}$ & 0.045 & 0.018 & 0.001 & -0.106 \\
\hline 21. & $\begin{array}{l}\text { SAM Syariah } \\
\text { Berimbang }\end{array}$ & 0.066 & 0.007 & 0.002 & -0.938 \\
\hline
\end{tabular}

to be invested. The Sharia mutual funds that have a positive performance reflected the resulting return that exceeded the risk-free investment return. The greater the Treynor Ratio, the better the performance of the Sharia mutual fund. It was because it could provide a high return on a systematic risk or the risk systematic borne. Table 2 also shows that based on the performance calculations using the Treynor Ratio, the best performance by the Mandiri Investa Dana Syariah with Treynor Ratio of 0.028 and the lowest performance by PNM Amanah Syariah with a Treynor value of -0.655 .

While using the Jensen Alpha, there are 9 Sharia mutual funds that have a positive performance, and 12 other Sharia mutual funds with a negative performance. This indicated that by using the Jensen Alpha, there were only 9 Sharia mutual funds that had a higher actual return than their expected return and deserved to be an investment choice. The Sharia mutual funds that have the best performance in Jensen Alpha is PNM Syariah with a value of 0.006 and the lowest performance is by PNM Ekuitas Syariah which has a value of -0.006 .

In the performance measurement results by using other method, namely the Information Ratio, it shows that there are 12 Sharia mutual funds with a positive performance and 9 Sharia mutual funds with a negative performance. The Sharia mutual funds that have a positive performance in the method of Information Ratio indicated that they had better performance, or above market performance (outperform), in this case, in the Jakarta Islamic Index (JII). Therefore, it could be concluded that about $57 \%$ of the proportion of Sharia mutual funds sampled in this study had performed beyond their market performance (outperform). The result of performance measurement using the Information Ratio method shows that the best performance is by Manulife Syariah Sektoral Amanah with the value of 0.796 and the lowest performance is by Cipta Syariah Equity which has a value of -3.362 .

Table 3. Sharia mutual funds with positive performance in Sharpe Index, Treynor Ratio, Jensen Alpha and Information Ratio (source: Pusat Data Kontan (2017) and Financial Services Authority (2017b), processed)

\begin{tabular}{|c|l|c|c|c|c|}
\hline No. & $\begin{array}{l}\text { Mutual Fund } \\
\text { Name }\end{array}$ & $\begin{array}{c}\text { Sharpe } \\
\text { Index }\end{array}$ & $\begin{array}{c}\text { Treynor } \\
\text { Ratio }\end{array}$ & $\begin{array}{c}\text { Jensen } \\
\text { Alpha }\end{array}$ & $\begin{array}{c}\text { Infor- } \\
\text { mation } \\
\text { Ratio }\end{array}$ \\
\hline 1. & PNM Syariah & 0.211 & 0.019 & 0.006 & 0.558 \\
\hline 2. & $\begin{array}{l}\text { Mandiri Investa } \\
\text { Dana Syariah }\end{array}$ & 0.108 & 0.028 & 0.005 & 0.559 \\
\hline 3. & $\begin{array}{l}\text { MNC Dana } \\
\text { Syariah }\end{array}$ & 0.074 & 0.016 & 0.000 & 0.005 \\
\hline 4. & $\begin{array}{l}\text { Manulife } \\
\text { Syariah Sektoral } \\
\text { Amanah }\end{array}$ & 0.025 & 0.002 & 0.001 & 0.796 \\
\hline 5. & $\begin{array}{l}\text { TRIM Syariah } \\
\text { Saham }\end{array}$ & 0.06 & 0.005 & 0.002 & 0.561 \\
\hline
\end{tabular}


Overall, based on the calculations using the Sharpe Index, Treynor Ratio, Jensen Alpha, and Information Ratio, it shows that there are five Sharia mutual funds that have a positive performance out of 21 samples of Sharia mutual funds that can be seen in Table 3 . Table 3 also shows five Sharia mutual funds that have consistently positive performance based on four performance measurements used, meaning that the Sharia mutual funds had an efficient portfolio. The five Sharia mutual funds that have consistently positive performance comes from three Sharia fixed income mutual funds and two others are classified as the Sharia equity mutual funds. The result of this study that the PNM Syariah has a positive performance also supports a research by Sunarsih and Andriyanto (2015).

The existence of three Sharia fixed income mutual funds that have consistent positive performance could occur since the reference interest rate was moving along with the downtrend. This was consistent with the researches results by Brandi (2002), Pangestuti et al. (2017), Pilotte and Sterbenz (2006). Andi and Kartini (2017) stated the decline in the benchmark interest rate will raise the bond price which is the focus of investment fund allocation in fixed income mutual funds category, so that the lower interest rate of Bank Indonesia will provide a positive sentiment on the performance of the bond market that can boost the performance of fixed income mutual funds.

The important finding of this study was that the positive performance of Sharia equity mutual funds was inseparable from the increasing (bullish) trend in the Jakarta Islamic Index during the research period. The Jakarta Islamic Index is an index that reflects the general stock prices that belong to the category of Sharia. Therefore, it was certainly profitable for the Sharia equity mutual funds which diversified their assets in Sharia stocks that were generally reflected in the Jakarta Islamic Index.

\section{Conclusions}

The purpose of this study was to compare each Sharia mutual fund performance in order to find out the best and the lowest performance of Sharia mutual funds and to compare the performance of Sharia mutual funds with market performance in order to understand whether the performance of a mutual fund managed by a better investment management was outperformed or underperformed than market performance, so it is expected to be an information for the investors in choosing Sharia mutual fund products.

This study found that by using Sharpe method, the best performance of Sharia mutual fund was by the PNM Syariah with the value of 0.211 and the lowest performance was by the PNM Amanah Syariah which had a value of -0.257 . Meanwhile, by using the Treynor method, it was found that the best Sharia mutual fund performance was by the Mandiri Investa Dana Syariah which had a value of 0.028 and the lowest performance was by the PNM Amanah Syariah with a value of -0.655 .

While in other methods, namely the Jensen method, it was found that the best performance was by the PNM Syariah with a value of 0.006 . These results were consistent with the Sharpe measurement methods. However, the performance of the lowest Sharia mutual fund in the Jensen method was different from the results of the Sharpe and Treynor methods, which were performed by the PNM Ekuitas Syariah with a value of -0.006 . Different results with other methods were also found in the measurement using the Information Ratio where the performance of the best Sharia mutual fund was by the Manulife Syariah Sektoral Amanah which had a value of 0.796 , while the lowest performance was by the Cipta Syariah Equity with a value of -3.362 .

The results of this study proved that from all 21 samples used, based on the measurement results using Sharpe Index, Treynor Ratio, Jensen Alpha, and Information Ratio, there were only 4 Sharia mutual funds that had a positive and consistent performance during the 2011-2016 study period. They are the Mandiri Investa Dana Syariah, Trim Syariah Saham, MNC Dana Syariah, and Manulife Syariah Sektoral Amanah. These findings can give a guidance for Sharia compliance investors in Indonesia. The investors should invest their funds in the Sharia mutual funds that have a consistently positive performance into their portfolios, as a positive performance consistently signifies that the Sharia mutual funds have an efficient portfolio, or in other words their assets are well diversified, resulting in the maximum returns compared to the risks they incurred.

The results of this study are expected to be useful for Sharia-based investors in Indonesia and for investors in other countries who will conduct Sharia-based investments in Indonesia.

\section{References}

Abdul-Rahman A, Yazid Z (2015) Developing a framework of Islamic bank operational risk management: 'people risk'. Jurnal Pengurusan 44: 129-139.

Andi D, Kartini D (September 25, 2017) Bunga turun, reksadana pendapatan tetap untung http://investasi.kontan.co.id/news/ bunga-turun-reksadana-pendapatan-tetap-untung

Arifin Z (2017) Testing for persistence in Sharia mutual fund performance in Indonesia. Review of Integrative Business and Economics Research 7 (1): 104-115.

Beer FM, Estes JP, Munte HJ (2011) The performance of faith and ethical investment products: an empirical investigation of the last decade. Journal of the Academy of Business and Economics 30: 101-124.

BI (2018) BI Rate http://www.bi.go.id/id/moneter/bi-rate/data/ Default.aspx 
Brandi JT (2002) Sharpe/Treynor performance attribution model: a practitioner's approach to using the Sharpe and Treynor reward to risk ratios. Journal of Pension Planning and Compliance 28 (2): 1-22.

Ferruz L, Gómez-Bezares F, Vargas M (2010) Portfolio theory, CAPM and performance measures. In: Lee C-F, Lee A, Lee J (Eds). Handbook of Quantitative Finance and Risk Management. Springer US, 267-281. https://doi.org/10.1007/9780-387-77117-5_17

Hilman L (2017) Performance of Sharia equity funds and conventional equity funds, which one is better? Paper presented at the The 3rd International Conference on Economics \& Banking 2017 (3rd ICEB).

Ismal R (2009) Model of Islamic monetary operation for liquidity management in Islamic banking: case of Indonesia 2000-2009. Gadjah Mada International Journal of Business 11 (2): 149-165. https://doi.org/10.22146/gamaijb.5528

Jensen MC (1967) The performance of mutual funds in the period 1945-1964. Journal of Finance 23 (2): 389-416. https://doi. org/10.1111/j.1540-6261.1968.tb00815.x

Kidd D (2011a) Measures of risk-adjusted return: let's not forget Treynor and Jensen. Investment Performance Measurement Feature Articles (1).

Kidd D (2011b) The sharpe ratio and the information ratio. Investment Performance Measurement Feature Articles 1: 1-4.

Kontan (2017) Nilai Aktiva Bersih [Net Asset Value] https:// pusatdata.kontan.co.id/reksadana/

Lakaba A, Robiyanto R (2018) Evaluasi kinerja saham bertanggungjawab sosial (Studi pada saham-saham yang masuk perhitungan indeks SRI-Kehati). Jurnal Organisasi Dan Manajemen 14 (2): 94-106.

Lestari WR (2015) Kinerja Reksadana Saham Syariah dan Reksadana Saham Konvensional. Jurnal Magister Manajemen 1: 116-128.

Loeis HP, Prijadi R (2015) Ambiguity towards Multiple historical performance information signals: evidence from Indonesian open-ended mutual fund investors. Indonesian Capital Market Review 7 (2): 92-101. https://doi.org/10.21002/icmr. v7i2.4846

Markowitz HM (1952) Portfolio selection. Journal of Finance 7 (1): 77-91.

Markowitz HM (1959) Portfolio selection: efficient diversification of investments. New York: John Wiley \& Sons, Inc.

Nadifa A (2016) Analisis Kinerja Reksa Dana Saham Dengan Menggunakan Metode Sharpe, Treynor, Jensen dan Information Ratio. Jurnal Universitas Islam Indonesia.

OJK, FS. A (2017a) Statistik Pasar Modal 2016 (Capital Market Statistics 2016). In F. S. A. OJK (Ed.). Jakarta, Indonesia.

OJK, FSA (2017b) Statistik Pasar Modal 2017 (Capital Market Statistics 2017). In FSA OJK (Ed). Jakarta, Indonesia.

Pangestuti IRD, Wahyudi S, Robiyanto R (2017) Performance Evaluation of equity mutual funds in Indonesia period of 2012-2014. Jurnal Keuangan dan Perbankan 21 (4): 527-542.
Pilotte EA, Sterbenz FP (2006) Sharpe and Treynor Ratios on Treasury Bonds. Journal of Business 79 (1): 149-180. https:// doi.org/10.1086/497409

Pratomo EP, Nugraha U (2009) Reksa Dana: Solusi Perencanaan Investasi di Era Modern. Jakarta: Gramedia Pustaka Utama.

Qomariah N, Sari MI, Budiarti DA (2016) Perbandingan Kinerja Reksadana Syariah dan Reksadana Konvensional (Pada Reksadana Saham dan Reksadana Pendapatan Tetap Yang Terdaftar di BEI Periode 2010-2014). Jurnal Keuangan dan Perbankan 20 (3): 417-427.

Robiyanto R (2017) Performance evaluation and risk aversion rate for several stock indices in Indonesia Stock Exchange. Jurnal Manajemen dan Kewirausahaan 19 (1): 60-64. https:// doi.org/10.9744/jmk.19.1.60-64

Robiyanto R (2018) Performance evaluation of stock price indexes in the Indonesia Stock Exchange. International Research Journal of Business Studies 10 (3): 173-182. https://doi. org/10.21632/irjbs.10.3.173-182

Robiyanto R, Wahyudi S, Pangestuti IRD (2017) The volatility - variability hypotheses testing and hedging effectiveness of precious metals for the Indonesian and Malaysian capital markets. Gadjah Mada International Journal of Business 19 (2): 167-192. https://doi.org/10.22146/gamaijb.26260

Sahri S, Seto AA, Syahyuni (2015) Comparative performance analysis of Sharia mutual funds in Indonesia Stock Exchange and Malaysia Exchange. International Seminar FEUM 2015 Reorienting Economics \& Business in The Context of National and Global Development, 80-96.

Sharpe WF (1966) Mutual fund performance. Journal of Business 39 (1): 119-138. https://doi.org/10.1086/294846

Sukmana R, Febriyati NA (2016) Islamic banks vs conventional banks in Indonesia: an analysis on financial performances. Jurnal Pengurusan 47: 81-90. https://doi.org/10.17576/pengurusan-2016-47-07

Sunarsih U, Andriyanto (2015) Analysis of the performance of Islamic mutual funds in Indonesia by using Sharpe, Treynor and Jensen the Period 2010-2012. Research Journal of Finance and Accounting (6): 125-133.

Treynor JL (1965) How to rate management of investment funds. Harvard Business Review 43 (1): 63-75.

Triyono D, Robiyanto R (2017) The effect of foreign stock indexes and Indonesia's macroeconomics variables toward Jakarta Composite Stock Price Index (JCI). Advanced Science Letters 23 (8): 7211-7214. https://doi.org/10.1166/asl.2017.9332

Wahyudi S, Nofendi D, Robiyanto R, Hersugondo H (2018) Factors affecting return on deposit (ROD) of Sharia banks in Indonesia. Business: Theory and Practice 19: 166-176. https:// doi.org/10.3846/btp.2018.17

Waridah W, Mediawati E (2016). Analisis Kinerja Reksadana Syariah. Riset Akuntansi dan Keuangan (4): 1077-1086.

Zulkafli AH, Ahmad ZMEE (2017) The Performance of socially responsible investments in Indonesia: a study of the Sri Kehati Index (SKI). Gadjah Mada International Journal of Business 19 (1): 59-76. https://doi.org/10.22146/gamaijb.17959 